\title{
Indications and timing of renal replacement therapy
}

\author{
Rolando Claure-Del Granado 1 and Etienne Macedo²
}

${ }^{1}$ Hospital Obrero \#2 - CNS, Universidad Mayor de San Simon, School of Medicine, Cochabamba, Bolivia; ${ }^{2}$ Department of Medicine, Nephrology Division, University of California San Diego, EE.UU.

\begin{abstract}
The management of patients with acute kidney injury is mainly supportive in nature, with no available proven therapeutic modalities to treat the condition. Renal replacement therapy (RRT) is indicated in patients with severe kidney injury, or increased volume or metabolic demands. In the absence of clinically significant uremic symptoms or specific indications such as severe electrolyte abnormalities or volume overload, the optimal timing of RRT initiation is controversial. Randomized, controlled trials that have compared strategies of early versus delayed initiation of RRT in the absence of obvious indications have yielded conflicting results. The implementation of decision support systems is challenging but could provide clinicians a framework with specific recommendations for interventions. Recently, some algorithms have been proposed to guide physicians in the decision to initiate, and their application in clinical practice may reduce variations across physicians and centers. The decision on the appropriate time to start RRT is complex, integrating numerous variables, and should largely be individualized, however the lack of definitive parameters to define early or late initiation reveals a great need to continue research on this field. Such evidence is important for reducing variations in the clinical practice of RRT prescription and improving patient outcomes.
\end{abstract}

KEY WORDS: Renal replacement therapy. Timing. Acute kidney injury. Early therapy. Delay therapy.

\section{Resumen}

El tratamiento de la lesión renal aguda es principalmente de soporte, ya que no se disponen de terapias efectivas para tratar esta enfermedad. La terapia de reemplazo renal (TRR) esta indicada en pacientes con lesión renal aguda secundaria a sepsis grave, o cuando existen demandas metabólicas incrementadas o sobrecarga de volumen. El tiempo de inicio óptimo de TRR en ausencia de síndrome urémico clínicamente significativo, o cuando existen indicaciones especificas como alteraciones en los electrolitos o sobrecarga de volumen es controversial. Estudios clínicos aleatorizados y controlados que han comparado estrategias de inicio temprano versus inicio tardío de TRR han mostrado resultados contradictorios. La implementación de un sistema de soporte para la toma de decisiones constituye un reto, pero podría proveer a los clínicos una estructura con recomendaciones especificas para intervenciones terapéuticas. Recientemente, se han propuesto algunos algoritmos para guiar a los médicos en la toma de decisiones acerca de cuando iniciar la TRR, y la aplicación de estos algoritmos en la practica clínica podría reducir la variabilidad en relación a la toma de decisiones entre diferentes médicos y centros. La decisión en cuanto al tiempo ideal de inicio de TRR es complejo, integra varias variables, y debiera ser individualizado; sin embargo, la falta de parámetros categóricos para definir un inicio temprano versus un inicio tardío nos muestran la necesidad de seguir investigando en esta área. Tal evidencia es importante para reducir la variaciones en la práctica clínica de la prescripción de TRR y para mejorar los desenlaces en los pacientes.

PALABRAS CLAVES: Terapia de reemplazo renal. Tiempo de inicio. Lesión renal aguda. Terapia temprana. Terapia tardía.

\author{
Correspondence: \\ Rolando Claure-Del Granado \\ Hospital Obrero \#2 - C.N.S. \\ Universidad Mayor de San Simon, School of Medicine Date of reception: 23-11-2017 \\ Cochabamba, Bolivia \\ Date of acceptance: 08-03-2018 \\ E-mail: rclaure@yahoo.com \\ DOI: 10.24875/GMM.M18000068
}
Gac Med Mex. 2018;Suup 1:15-21
Contents available at PubMed www.anmm.org.mx 


\section{Introduction}

When renal function acutely declines, and fluid and metabolic demands are increased, renal replacement therapy (RRT) is the only available treatment for acute kidney injury (AKI). However, in the absence of life-threatening situations, the tendency is to avoid RRT as long as possible. This thought process reflects the decisions made for patients with end-stage renal disease in whom the initiation of RRT is associated with dialysis dependency. In critically ill patients with AKI, absolute indications for RRT include: severe acidosis, fluid overload with oliguria that does not response to the use of diuretics, hyperkalemia, and signs/symptoms of uremia. In the absence of absolute or urgent life-threatening indications, the optimal time to start RRT is unknown ${ }^{1-3}$. Nevertheless, the presence of AKI complications such as signs/symptoms of uremia can increase AKI mortality risk and be considered "late" for dialysis initiation (Table 1$)^{4}$. A better approach to evaluate timing for RRT initiation would be based on clinical criteria including presence and degree of other organs dysfunction, rather than biochemical evidence of uremia. Early intervention would allow for better control of fluids and solutes and promote the return of renal function ${ }^{5-7}$. The benefits of supporting other organs depend on the balance between the current load associated with the clinical conditions and the ability of the kidneys to manage fluid and the metabolic load. Consequently, the initiation of RRT should be prompted by the inability of the kidney to meet the demands being placed on them ${ }^{8,9}$. Although a recent study shows that clinicians are less commonly utilizing AKI staging as a criterion for initiating RRT ${ }^{2}$, the tendency is still to delay initiation if renal recovery is possible. Concerns associated with the RRT procedure such as hypotension, arrhythmias, and complications with the vascular access and the use of anticoagulation is the most common reasons to avoid RRT. In addition, the potentially deleterious effect of "early" RRT initiation on renal recovery caused by hemodynamic instability, and vascular catheter-related bacteremia and sepsis further delay the decision to initiate it ${ }^{3}$.

\section{Defining timing of RRT Initiation}

There is no consensus on how to properly define timing of RRT initiation in AKI. Most studies that have addressed the issue of timing have used several terms for their study methodologies such as "early," "accelerated," "delayed," "late," and "standard" initiation of RRT and have applied various definitions to differentiate early versus late initiation of $\mathrm{RRT}^{7,10,11}$. It is important to mention that early or late initiation of RRT will depend on the clinical context of each individual patient, making the use of these terms relative. The definitions used for timing in RRT have integrated physiological parameters such as urine output and biochemical parameters such as serum creatinine, timing relative to the development of $\mathrm{AKI}$, timing relative to hospital or ICU admission, and timing relative to complications of $\mathrm{AKI}$, or conventional indications for starting RRT such as hyperkalemia, acidosis, or fluid overload. This heterogeneity in how the timing and the threshold for starting RRT have been defined represent significant challenges and fundamental obstacles in progress on this field ${ }^{12}$. Furthermore, one aspect that most studies have not considered is withholding RRT. It is possible that conservative management of these patients consisting of supportive management, watchful waiting, and initiation of RRT only when absolute or urgent indications develop may, in fact, result in the spontaneous recovery of kidney function by patients with severe $\mathrm{AKI}^{13}$. Recently a multicenter randomized controlled trial showed that $25 \%$ of patients randomized to a strategy of standard initiation of RRT recovered kidney function without receiving $\mathrm{RRT}^{14}$. In the standard arm at 90 days following enrollment, the mortality rate was $37 \%$ versus $38 \%$ in the accelerated $\mathrm{arm}^{14}$.

\section{Current clinical practice guidelines}

At present, we have two clinical practice guidelines for AKI that have made recommendations regarding the issue of timing of RRT: the kidney disease improving global outcomes (KDIGO) Consortium and the National Institute for Health and Care Excellence (NICE) in the United Kingdom ${ }^{1,15}$.

The KDIGO guidelines provided the following consensus recommendations:

a. Initiate RRT emergently when life-threatening changes in a fluid, electrolyte, and acid-base balance exist (not rated).

b. Consider the broader clinical context, the presence of conditions that can be modified by RRT, and trends of laboratory test results rather than absolute values of blood urea nitrogen (BUN) or serum creatinine when making the decision of when to start RRT (not rated). 
Table 1. Absolute and relative renal indications and contraindications for renal replacement therapy initiation in critically ill patients with acute kidney injury

\begin{tabular}{|c|c|c|c|}
\hline Indications & Absolute & Relative & Relative contraindications \\
\hline $\begin{array}{l}\text { Metabolic } \\
\text { disorders }\end{array}$ & $\begin{array}{l}\text { - BUN>100 mg/dl } \\
\text { - Hyperkalemia >6 mEq/l with } \\
\text { ECG abnormalities } \\
\text { - Hypermagnesemia >8 mEq/l } \\
\text { with anuria and absent deep } \\
\text { tendon reflexes }\end{array}$ & $\begin{array}{l}\text { - BUN }>76 \mathrm{mg} / \mathrm{dl} \\
\text { - Hiperkalemia }>6 \mathrm{mEq} / \mathrm{l} \\
\text { - Hypermagnesemia }>8 \mathrm{mEq} / \mathrm{l} \\
\text { - Dysnatremia }\end{array}$ & $\begin{array}{l}\text { - Futile prognosis } \\
\text { - Patient receiving palliative care } \\
\text { - High likelihood of non-recovery of renal } \\
\text { function in a patient who is not a candidate } \\
\text { for long-term dialysis }\end{array}$ \\
\hline Acidosis & $\begin{array}{l}\text { - } \mathrm{pH}<7.15 \\
\text { - Lactic acidosis related to } \\
\text { metformin use }\end{array}$ & $\mathrm{pH}>7.15$ & \\
\hline Oliguria/Anuria & & AKIN stage 1,2 or 3 & \\
\hline Fluid overload & - Diuretic resistant & Diuretic sensitive & \\
\hline Overdose/toxicity & - From a dialyzable drug or toxin & $\begin{array}{l}\text { - Concomitant accumulation of } \\
\text { poisons or toxic drugs that can be } \\
\text { removed by RRT (e.g., salicylates, } \\
\text { ethylene glycol, methanol, metformin) }\end{array}$ & \\
\hline
\end{tabular}

BUN: blood urea nitrogen; ECG: electrocardiogram; AKIN: acute kidney injury network; RRT: renal replacement therapy.

The KDIGO guidelines leave the final decision to start RRT to the attending physician in the context of deterioration of kidney function or any worsening of the patient clinical condition, without any definitive recommendation.

Similarly, the NICE clinical practice guidelines for AKI have proposed the following recommendations:

a. Immediately discuss any potential indication of RRT with a nephrologists and/or a critical care specialist to ensure that the therapy is started as soon as needed.

b. Immediately refer patients for RRT if any of the following are not responding to medical management:

- Hyperkalemia

- Metabolic Acidosis

- Complications of uremia (e.g., pericarditis and encephalopathy)

- Fluid overload

- Pulmonary edema.

c. Base the decision of when to start RRT on the condition of the patient as a whole rather than on isolated indicator such us the BUN, creatinine, or potassium level.

Like KDIGO Clinical Practice Guidelines, NICE Guidelines also recognized the paucity of high-quality evidence for decision-making about when to start RRT. NICE guidelines also highlight the need of better tools such as biomarkers or risk prediction scores that would allow clinicians to better discriminate patients who have a high probability of developing worsened $A K I$ or complications related to AKI in whom RRT will benefit from patients who have a high probability of recovering kidney function and who may benefit from conservative strategy.

\section{What evidence we currently have?}

Several studies have recently tried to address the question of timing in RRT in critically ill patients with AKI. A summary of these trials is shown in table 2. Observational studies have suggested that early RRT may improve survival 10,11,16; however, conclusions that could be drawn from available observational data are limited because of the retrospective design of the study or post hoc analysis, the heterogeneity of the cohort, and the different definitions and thresholds for RRT initiation. Another issue with observational studies is that they did not compare patients with AKI that received RRT with patients who did not; except for the Finish AKI (FINNAKI) study ${ }^{17}$. This study included 239 critically ill patients with AKI and treated with RRT. The FINNAKI study compared 3 timing RRT strategies: pre-emptive if RRT was started in the absence of hyperkalemia, severe academia, uremia, oligoanuria, and fluid overload with pulmonary edema; "classic-urgent" if started within $12 \mathrm{~h}$ of developing one of the indications mentioned above; and "classic-delayed" if started $>12 \mathrm{~h}$ after developing one of these indications. "Pre-emptive" RRT was associated with lower 90-day mortality as compared to "classic-urgent" RRT (30 vs. $49 \%$; odds ratio $2.1,95 \% \mathrm{Cl}, 1.0-4.1$ ). This same association was found when "classic-urgent" RRT was compared to "classic-delayed" RRT (39 vs. 


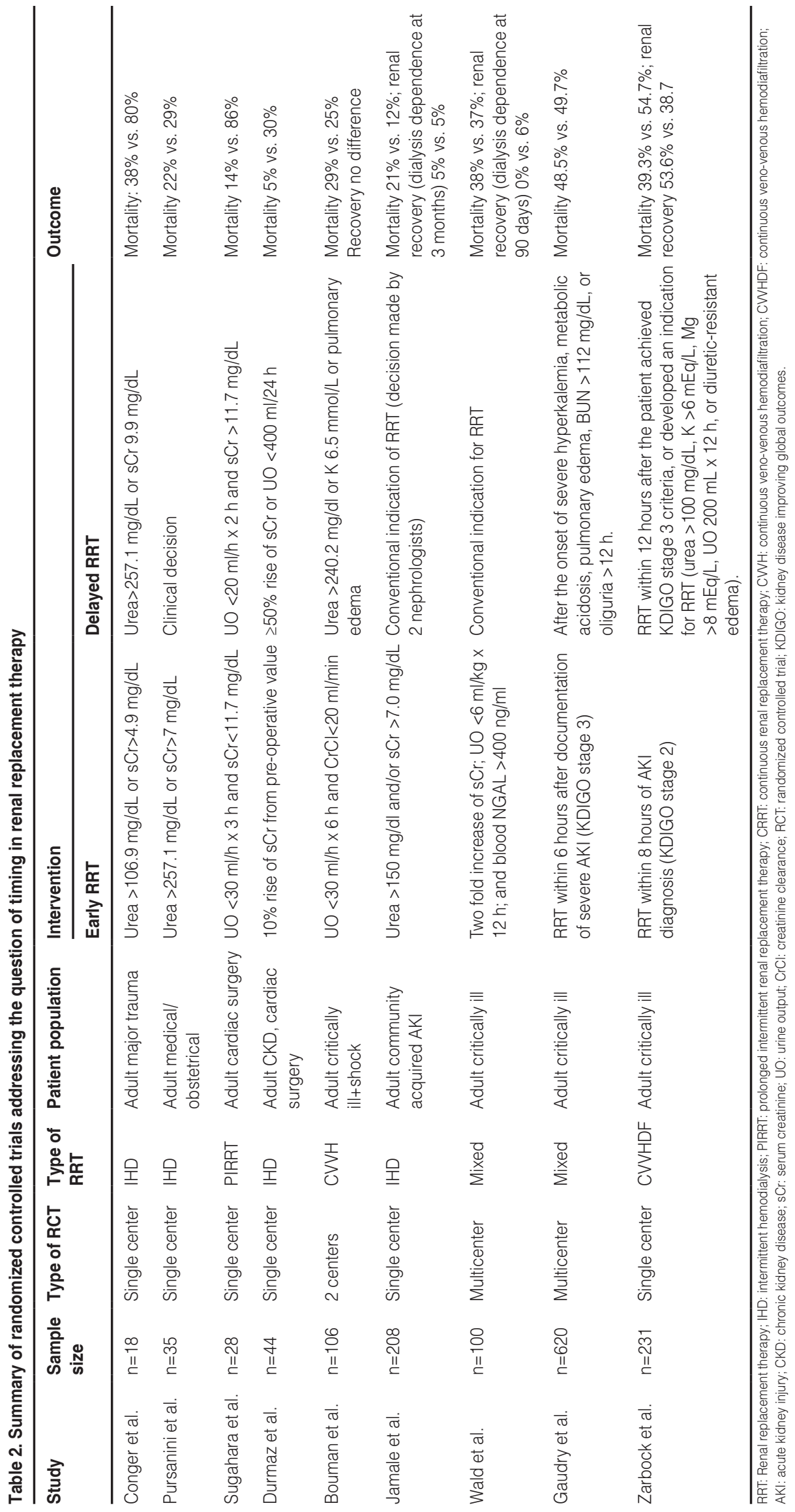


$68 \%$; odds ratio $3.9 ; 95 \% \mathrm{Cl}, 1.5-10.2)$. The mortality rate was also lower in patients with "pre-emptive" RRT than in patients not receiving RRT.

Several small prospective randomized trials have been recently performed. Most of these are the observational studies, we mentioned above which show some beneficial effects of an early initiation of RRT in critically ill patients with $A K I^{18-20}$.

However, a meta-analysis of 10 randomized trials showed no benefit of early initiation on 30-day, 60-day, or 90-day mortality ${ }^{21}$. There was also no difference between early and late initiation on the risk of dialysis dependence, length of intensive care unit or hospital stay, or recovery of renal function. However, this analysis is also limited in part because of the heterogeneity due to variable definitions of early versus late initiation.

Three of the largest trials that were included in this meta-analysis demonstrated no benefit with earlier initiation of $\operatorname{RRT}^{14,22,23}$. The best data are from the artificial kidney initiation in kidney injury trial, a multicenter, randomized trial that included 620 patients that had severe $\mathrm{AKI}$ and required either mechanical ventilation, catecholamine infusion, or both ${ }^{22}$. Severe AKI was defined using KDIGO Stage 3 criteria (an increase in serum creatinine to 3 times baseline, or increase in serum creatinine to $\geq 4.0 \mathrm{mg} / \mathrm{dL}$, or reduction in urine output to $<0.3 \mathrm{~mL} / \mathrm{kg} / \mathrm{h}$ for $\geq 24 \mathrm{~h}$, or anuria for $\geq 12 \mathrm{~h}$ ). Patients were excluded if they had BUN > $112 \mathrm{mg} / \mathrm{dL}$, serum potassium $>6 \mathrm{Eq} / \mathrm{L}$ (or $>5.5 \mathrm{mEq} / \mathrm{L}$ despite medical intervention), $\mathrm{pH}<7.15$, or pulmonary edema (requirement for oxygen flow rate $>5 \mathrm{~L} / \mathrm{min}$ to maintain $\mathrm{O}_{2}$ saturation $>95 \%$ or among intubated patients and requirement for fraction of inspired oxygen $>50 \%$ ). These patients were excluded because they were considered to have an "urgent" indication for RRT.

Patients were assigned to a strategy of early RRT (within $6 \mathrm{~h}$ after documentation of severe AKI) or to a strategy of delayed RRT initiation (initiation after the onset of severe hyperkalemia, metabolic acidosis, or pulmonary edema, all defined by parameters included in the exclusion criteria listed above, or after an increase in BUN > $112 \mathrm{mg} / \mathrm{dL}$, or development of oliguria for more than $72 \mathrm{~h}$ after randomization).

The study showed no benefit associated with the early RRT strategy. Mortality at 60 days was not different between the early and late strategy groups ( $48.5 \%$ vs. $49.7 \%$, respectively; $p=0.79$ ). $49 \%$ of the patients in the delayed strategy group never received RRT. Diuresis occurred earlier in the delayed-strategy group, possibly suggesting a renal recovery in this group. Compared with the delayed strategy group, catheter-related infections ( $5 \%$ vs. $10 \%)$, and hypophosphatemia ( $5 \%$ vs. $22 \%$ ) were more common in the early strategy group.

The other two studies were smaller and have also shown no benefit associated with early initiation, although results need to be interpreted with caution as both trials were underpowered to detect mortality differences ${ }^{14,23}$.

The early versus late initiation of RRT in critically ill patients with AKI (ELAIN) study was a single-center, randomized trial that showed a survival benefit conferred by early initiation of RRT ${ }^{24}$. This trial included 231 critically ill patients with moderate AKI, as defined by KDIGO Stage 2 criteria (including creatinine $\geq$ 2 times baseline or urinary output $<0.5 \mathrm{~mL} / \mathrm{kg} / \mathrm{h}$ ). All patients also had severe sepsis, required vasopressors, or had refractory volume overload. Patients were assigned to early RRT initiation (within $8 \mathrm{~h}$ of AKI diagnosis) or delayed or no initiation. Patients in the delayed or no initiation group received RRT within $12 \mathrm{~h}$ after the patient achieved KDIGO Stage 3 criteria or developed an indication for RRT (such as serum urea level $>100 \mathrm{mg} / \mathrm{dL}$, potassium $>6 \mathrm{mEq} / \mathrm{L}$, serum magnesium $>8 \mathrm{mEq} / \mathrm{L}$, urine output $200 \mathrm{~mL}$ over $12 \mathrm{~h}$, or diuretic-resistant edema). In the delayed initiation group, 11 patients ended up not receiving RRT; of these, only six patients did not progress to Stage 3, three patients had a recovery of renal function, and three patients died. Compared with delayed or no initiation, early RRT initiation reduced 90-day mortality (hazard ratio, $0.66,95 \% \mathrm{Cl} 0.45-0.97$ ). Furthermore, more patients recovered renal function in the early versus delayed group by 90 days (odds ratio 0.55 , $95 \% \mathrm{Cl} 0.32-0.93$ ), and both the duration of RRT and the hospital stay were shorter in the early-initiation group. However, although this was a carefully performed trial, it is difficult to understand how such small differences in the timing of dialysis initiation could achieve such improvement in outcomes.

Other randomized trials, including Initiation of Dialysis Early versus Delayed in Intensive Care Unit (IDEAL-ICU; NCT01682590) and Standard versus Accelerated Initiation of RRT in AKI (STARRT-AKI; NCT02568722), are underway and may allow more definitive conclusions to be drawn.

\section{Some proposed approaches}

In light of contradictory results of the observational studies and a clinical trial evaluating the effect of 


\begin{tabular}{|c|c|c|c|}
\hline \multirow[t]{2}{*}{ Situation } & \multicolumn{3}{|c|}{ Indication to start RRT } \\
\hline & More urgent & Less urgent & Non-urgent indications \\
\hline Acid-base & Metabolic acidosis, $\mathrm{pH}<7.2$ & $\mathrm{pH} 7.2-7.3$ & $\mathrm{pH}>7.3$ or not available \\
\hline Electrolyte & $\mathrm{K}>6.5 \mathrm{mEq} / \mathrm{L}$ or EKG changes & $\mathrm{K} 6.0-6.5 \mathrm{mEq} / \mathrm{L}$ & $\mathrm{K}<6.0 \mathrm{mEq} / \mathrm{L}$ \\
\hline Ingestion & Ingestion of toxins & N/A & N/A \\
\hline Overloaded & $\begin{array}{l}\text { Massive anasarca } \\
\text { Respiratory failure, } \mathrm{FiO}_{2}>0.7 \\
\text { UO }<100 \mathrm{ml} \times 24 \text { hours }\end{array}$ & $\begin{array}{l}\text { Edema } 2-3+ \\
\text { Hypoxemia, } \mathrm{FiO}_{2} \text { 0.5-0.7 } \\
\text { UO } 100-500 \mathrm{ml} \times 24 \text { hours }\end{array}$ & $\begin{array}{l}\text { Edema } 1+ \\
\text { UO }>500 \mathrm{ml} 24 \times \text { hours }\end{array}$ \\
\hline Uremia & $\begin{array}{l}\text { Uremic symptoms } \\
\text { Altered mental status }\end{array}$ & BUN $60-130 \mathrm{mg} / \mathrm{dL}$ & $\mathrm{BUN}<60 \mathrm{mg} / \mathrm{dL}$ \\
\hline Recommendation & $\begin{array}{l}\text { If any of these variables is } \\
\text { present start RRT }\end{array}$ & $\begin{array}{l}\geq 3 \text { variables present start RRT } \\
1-2 \text { variables present no RRT } \\
\text { need, reassess }\end{array}$ & Don't start RRT \\
\hline
\end{tabular}

Figure 1. Proposed approach for timing of RRT in patients with AKI (adapted from Mendu LM et al., 201726).

RRT: renal replacement therapy, N/A: nonassessed, UO: urine output, BUN: blood urea nitrogen

timing of RRT, some approaches have been proposed. Bagshaw et al. ${ }^{25}$ algorithm incorporate several patient-specific factors, based on evidence when available, that may decisively influence when to initiate RRT. In this algorithm, RRT is initiated if there is an absolute indication. If there is no absolute indication, it recommends optimizing resuscitation and the continuous assessment of: AKI severity and trend, illness severity and trajectory, and finally the response to resuscitation optimization (e.g. intravascular volume, cardiac output, and mean arterial blood pressure). If patient progressed to AKI Stage 3, the authors recommend considering RRT. If patient is on AKI Stage 1 or 2 , it is also suggested to consider initiation of RRT if any of the following situations are identified: rapidly worsening AKI or illness severity, hypercatabolic state, refractory fluid overload and/or accumulation, severe sepsis, permissive hypercapnia, reduce renal reserve, and low probability for early renal recovery.

More recently Mendu et al. ${ }^{26}$ proposed a decision-making algorithm for RRT initiation and discontinuation. The AKI Standardized Clinical Assessment and Management Plan algorithm provides recommendations to assist clinicians in deciding when to initiate or withhold dialysis on the basis of patient comorbidities and clinical parameters. They divided indications to start RRT into MORE URGENT and LESS URGENT, and they use the acronym AEIOU ( $\mathrm{A}=$ acidosis; $\mathrm{E}=$ Electrolyte; $\mathrm{I}=\mathrm{In}$ gestion; $\mathrm{O}=$ Overload; and $\mathrm{U}=$ Uremia) to evaluate important clinical aspects that will determine the decision to start RRT. If any of the MORE URGENT indications to start RRT is present, they recommend to initiating RRT; or if $\geq 3$ LESS URGENT indications are present. In the case of 1-2 less urgent indications, authors suggest withholding RRT. The authors also recommend not starting RRT in the patient has all the following non-urgent characteristics: $\mathrm{pH}>7.3$ or not available, $\mathrm{K}<6.0 \mathrm{mmoL} / \mathrm{L}$, no ingestion of toxins, $\leq 1+$ edema, urine output $>500 \mathrm{~mL}$ day, and $\mathrm{BUN}<60 \mathrm{mg} /$ $\mathrm{dL}$ (Fig. 1).

\section{Conclusions}

Based on recent observational and clinical trials, the optimal time for RRT initiation in critically ill patients 
with $\mathrm{AKI}$ is uncertain. Recent high-quality randomized controlled trials specifically focused on when to start RRT have shown conflicting results. Implementing a decision support system is challenging but could provide clinicians a framework with specific recommendations for interventions. Proposed algorithms could reduce practice variations across physicians and centers. Clearly, there is a great need to continue research in this field. Such evidence is important for reducing unnecessary variations in the clinical practice of RRT prescription. At present, the decision on when to start RRT is complex and should largely be individualized for each patient.

\section{References}

1. Copyright and License Information. Section 5: dialysis interventions for treatment of AKI. Kidney Int Suppl (2011). 2012;2:89-115.

2. Bagshaw SM, Uchino S, Bellomo R, et al. Timing of renal replacement therapy and clinical outcomes in critically ill patients with severe acute kidney injury. J Crit Care. 2009;24:129-40.

3. Clark E, Wald R, Levin A, et al. Timing the initiation of renal replacement therapy for acute kidney injury in canadian intensive care units: a multicentre observational study. Can J Anaesth. 2012;59:861-70.

4. Libório AB, Leite TT, Neves FM, Teles F, Bezerra CT. AKI complications in critically ill patients: association with mortality rates and RRT. Clin J Am Soc Nephrol. 2015;10:21-8.

5. Ostermann M, Chang RW. Correlation between parameters at initiation of renal replacement therapy and outcome in patients with acute kidney injury. Crit Care. 2009;13:R175.

6. Chou YH, Huang TM, Wu VC, et al. Impact of timing of renal replacement therapy initiation on outcome of septic acute kidney injury. Crit Care. 2011;15:R134.

7. Ostermann M, Dickie H, Barrett NA. Renal replacement therapy in critically ill patients with acute kidney injury when to start. Nephrol Dial Transplant. 2012;27:2242-8.

8. Macedo E, Mehta RL. When should renal replacement therapy be initiated for acute kidney injury? Semin Dial. 2011;24:132-7.

9. Mehta RL. Challenges and pitfalls when implementing renal replacement therapy in the ICU. Crit Care. 2015;19 Suppl 3:S9.
10. Karvellas CJ, Farhat MR, Sajjad I, et al. A comparison of early versus late initiation of renal replacement therapy in critically ill patients with acute kidney injury: a systematic review and meta-analysis. Crit Care. 2011;15:R72.

11. Seabra VF, Balk EM, Liangos $O$, et al. Timing of renal replacement therapy initiation in acute renal failure: a meta-analysis. Am J Kidney Dis. 2008;52:272-84.

12. Ostermann M, Wald R, Bagshaw SM. Timing of renal replacement therapy in acute kidney injury. Contrib Nephrol. 2016;187:106-20.

13. Bagshaw SM, Uchino S, Kellum JA, et al. Association between renal replacement therapy in critically ill patients with severe acute kidney injury and mortality. J Crit Care. 2013;28:1011-8.

14. Wald R, Adhikari NK, Smith OM, et al. Comparison of standard and accelerated initiation of renal replacement therapy in acute kidney injury. Kidney Int. 2015;88:897-904.

15. Ftouh S, Thomas M, Acute Kidney Injury Guideline Development Group. Acute kidney injury: summary of NICE guidance. BMJ. 2013;347:f4930.

16. Wang $X$, Jie Yuan W. Timing of initiation of renal replacement therapy in acute kidney injury: a systematic review and meta-analysis. Ren Fail. 2012;34:396-402.

17. Vaara ST, Reinikainen M, Wald R, et al. Timing of RRT based on the presence of conventional indications. Clin J Am Soc Nephrol. 2014:9:1577-85.

18. Gettings LG, Reynolds HN, Scalea T. Outcome in post-traumatic acute renal failure when continuous renal replacement therapy is applied early vs. late. Intensive Care Med. 1999;25:805-13.

19. Liu KD, Himmelfarb J, Paganini E, et al. Timing of initiation of dialysis in critically ill patients with acute kidney injury. Clin J Am Soc Nephrol. 2006;1:915-9.

20. Shiao CC, Wu VC, Li WY, et al. Late initiation of renal replacement therapy is associated with worse outcomes in acute kidney injury after major abdominal surgery. Crit Care. 2009;13:R171.

21. Bhatt GC, Das RR. Early versus late initiation of renal replacement therapy in patients with acute kidney injury-a systematic review \& meta-analysis of randomized controlled trials. BMC Nephrol. 2017;18:78.

22. Gaudry S, Hajage D, Schortgen F, et al. Initiation strategies for renal-replacement therapy in the intensive care unit. N Engl J Med. 2016; 375:122-33.

23. Jamale TE, Hase NK, Kulkarni M, et al. Earlier-start versus usual-start dialysis in patients with community-acquired acute kidney injury: a randomized controlled trial. Am J Kidney Dis. 2013;62:1116-21.

24. Zarbock A, Kellum JA, Schmidt C, et al. Effect of early vs delayed initiation of renal replacement therapy on mortality in critically ill patients with acute kidney injury: the ELAIN randomized clinical trial. JAMA. 2016;315:2190-9.

25. Bagshaw SM, Cruz DN, Gibney RT, Ronco C. A proposed algorithm for initiation of renal replacement therapy in adult critically ill patients. Crit Care. 2009;13:317.

26. Mendu ML, Ciociolo GR Jr., McLaughlin SR, et al. A decision-making algorithm for initiation and discontinuation of RRT in severe AKI. Clin J Am Soc Nephrol. 2017;12:228-36. 